\title{
Analysis of hydrogen enriched treble biofuel blended with diesel for performance, emission and combustion characteristics on CI engine
}

\author{
H.N. Md. Fakhruddin', Mohammed Yousuf Ali² and M. Manzoor Hussain ${ }^{3}$ \\ ${ }^{1}$ Mechanical Engineering Department, \\ Methodist College of Engineering and Technology - Hyderabad - 500001, India \\ Email: mfhnn@yahoo.com; Phone No.+919963584450 \\ ${ }^{2}$ Avanthi Institute of Engineering \& Technology \\ Gunthapally Village, Hayathnagar (M), RR Dist. Hyderabad-India \\ Email: yousufonline@yahoo.com; \\ Phone No. +919866301410 \\ ${ }^{3}$ JNTUH College of Engineering Kukatpally, Hyderabad (Autonomous) \\ Email: manzoorjntu@gmail.com; \\ Phone No. +919848211005
}

\begin{abstract}
The need of the hour is to look forward to alternative fuels to swipe out the dependence on fossil fuels, as biofuels from various feedstocks are being experimented worldwide. However, it is difficult to implement biodiesel from a single feedstock to replace the existing fossil fuels. It is reliable to obtain biodiesel from local feedstock and to make multiple biodiesel mixtures blended with diesel. The present work relies more on biofuels and acts as a step towards fossil fuel-free engine or at least to snatch the lion's share of the fossil fuels. In this contest, the experiment was carried out by using treble biofuels i.e., WCOBD + PSBD + Bio-hydrogen at different injection pressures (i.e., 200bar, 225bar and 250bar) and compared them with a similar engine that utilised fossil fuel as the stand-alone fuel. The mixture ratios were B10, B20 and B30 and the enrichment of hydrogen was done at $41 \mathrm{pm}, 6 \mathrm{lpm}$ and $81 \mathrm{pm}$. The results showed that the brake thermal efficiency of dual biofuel blended diesel decreased as compared to that of the base fuel and increased with hydrogen enriched biodiesel. Hence, the brake specific energy consumption decreased for the hydrogen enriched fuel and the exhaust emissions of CO and $\mathrm{CO}_{2}$ were reduced, however, NOx showed an increasing trend as usual.
\end{abstract}

Keywords: Bio-hydrogen, waste cooking oil biodiesel, palm biodiesel, treble blend and injection pressure.

\section{INTRODUCTION}

Nowadays, alternative fuels for diesel engines is an emerging topic among researchers due to decreasing petroleum reserve and hazardous health and environmental effects of engine exhaust gases. Edible-based biodiesel sources pertaining to food chain are not considered feasible due to price fluctuation, and land limitation, also, they are contrary to the current social movement and energy policies, therefore, their industrial expansion has been limited [1]. Biomass sources, particularly vegetables oils, have attracted much attention as alternative energy sources due to easy availability, renewable and cleaner burning than fossil fuels [2, 3]. In addition, biodiesel has lower sulphur and aromatic 
contents and net carbon dioxide $\left(\mathrm{CO}_{2}\right)$ emission. Biodiesel can be used immediately in diesel power generators without many modifications as it can be mixed at any proportion with diesel [3]. Besides that, biodiesel cost is a major concern for its commercialisation. Biodiesel produced from vegetable oil or animal fat is $10-15 \%$ more expensive than petroleum-based diesel fuel. The feedstock cost comprises approximately $70-95 \%$ of total operating costs of a biodiesel plant [2]. Locally available biofuel should be an alternative source for petroleum and able to be made in any local area [4]. Waste cooking oil (WCO) is one of biodiesel sources, unlike the high speed diesel (fossil fuel) that may cause harm in future. WCO is a renewable fuel extracted from the residual waste of used cooking oil. It is very cheap, non-volatile, safe to store, releases comparatively less carbon dioxide and has a cleaner exhaust. Depending on its source and availability, WCO costs less than neat vegetable oils. Hotels and other public eateries are the major contributors to WCO production. Over cooked WCO can cause adverse health issues like cataracts, liver damage and jaundice and can damage the immune system in children. Recycling is the best way to use WCO properly without compromising its adverse effects. Animal feed production is a major part of recycled $\mathrm{WCO}$ and a small portion is used to manufacture soaps and biodegradable lubricants. Consumption of food of animal origin like milk, meat, poultry and other products may cause undesirable contaminants to enter the human body and pose serious long term health hazards. Therefore, a major portion of the recycled WCO is available to be used as an alternative fuel in compression ignition (CI) engines after suitable modifications in the fuel properties [5, 6]. Palm oil is semi-solid at room temperature $\left(20^{\circ} \mathrm{C}\right)$. The liquid part may be physically separated from the solid part of palm oil via fractionation method. After fractionation, it is known as palm olein, which is commonly sold as cooking oil, while the solid fat portion is known as palm stearin, which is normally used to formulate trans-free fats such as margarine, soap, shortening and vegetable ghee.

Many refined virgin vegetable oils, such as palm, canola, soybean and corn, have been used to produce biodiesel to substitute petroleum diesel. Due to the high cost of cooking oils, palm stearin (PS) may become a promising alternative feedstock for biodiesel production. PS is the solid fraction obtained by fractionation of palm oil after crystallisation at a controlled temperature. It is not used directly for edible purposes due to its high melting point that ranges from 44 to $56^{\circ} \mathrm{C}$ [7]. The physical characteristics of PS differ significantly from those of palm olein. The high degree of saturation of PS poses problems in edible fats manufacturing as it confers low plasticity to the end product, thus, limiting the commercial exploitation of the material [7]. Renewable fuels are those produced from renewable resources in nature. Examples include biofuels e.g., ethanol and methanol from clean energy, vegetable oil used as fuel, carbon dioxide or biomass, biodiesel and hydrogen fuel (when produced with renewable processes). An important future application of hydrogen could be as an alternative for fossil fuels, only once the oil deposits are depleted. However, this application relies on the storing techniques development to enable a proper storage, effective distribution and good hydrogen combustion. If the cost of hydrogen production and distribution decreases, then end-user technologies could pick up and hydrogen fuel could be entering the market in 2020 [8].

Fossil energy source cannot be regenerated and will be exhausted with increasing fossil fuel consumptions. Hydrogen energy is a new energy source with abundant reserves and does not depend on fossil fuel. Moreover, hydrogen energy conforms to the requirement of the worldwide environmental protection, thus, receives more attention all over the world. Hydrogen may be produced in biosystem, which includes two ways of light-drive process and anaerobic fermentation, the former is theoretically a perfect 
process that transforms solar energy into hydrogen by photosynthetic bacteria. However, due to low utilisation efficiency of light and difficulties in designing light reactor, this method is hard to be applied in practice. The latter carries out anaerobic fermentation by hydrogen, which has many advantages, such as rapid, simple, easy operation and hydrogen production by renewable resources and organic waste [9]. Compared to the light-drive reactor, anaerobic fermentative hydrogen-production is easier to conduct and suitable for the demands of sustainable development strategy. At present, the yield and rate of hydrogen production are still low. With the rapid development of molecular biological technology, the directional heredity reconstruction for microbe becomes the new research hotspot, which can radically change microbial biological properties and metabolic modes to cultivate superior microbial strains more beneficial to bio-hydrogen production, economise costs and increase production efficiency and yield, and provide more efficient pathways for the exploitation and popularisation of hydrogen energy sources [10]. The objective of the paper is to experimentally analyse the performance, emission and combustion characteristics of diesel engine that runs on treble biofuels blended with diesel. Among them is hydrogen, that will boost the combustion due to its high calorific value and flame velocity.

\section{MATERIALS AND METHODS}

\section{Engine Specifications}

A performance test was carried out in a research engine test rig as shown in Figure 1 and the specification is tabulated in Table 2 . The uncertainties in the measured parameters in the present study are given in Table 1 .

Table 1. Uncertainties in measured experimental variables.

\begin{tabular}{lc}
\hline \multicolumn{1}{c}{ Make } & Kirloskar \\
\hline Number of cylinder & 1 \\
Number of stroke & 4 \\
Fuel & Diesel \\
Cooling Type & Water \\
Model & TV1 \\
Stroke length & $110 \mathrm{~mm}$ \\
Bore diameter & $87.5 \mathrm{~mm}$ \\
Volume & $661 \mathrm{cc}$ \\
Power & $3.5 \mathrm{kw}$ \\
Speed & $1500 \mathrm{rpm}$ \\
Compression ratio & 17 \\
Injection pressure & Variable injection pressure \\
Range & $200 \mathrm{bar}$ to $250 \mathrm{bar}$ \\
Loading unit & Eddy current \\
Dynamometer type & Eddy current \& Water cooled \\
\hline
\end{tabular}

\section{Variation of Injection Pressure}

The experiment was conducted at various injection opening pressures (IOPs) to find the optimum injection pressure at which a good engine performance can be obtained. Three different injection pressures i.e., 200bars, 225bars and 250bars were set by rotating the compression spring load screw until the associated pressure sensor displayed the desired value on the monitor. 
Table 2. Engine specification.

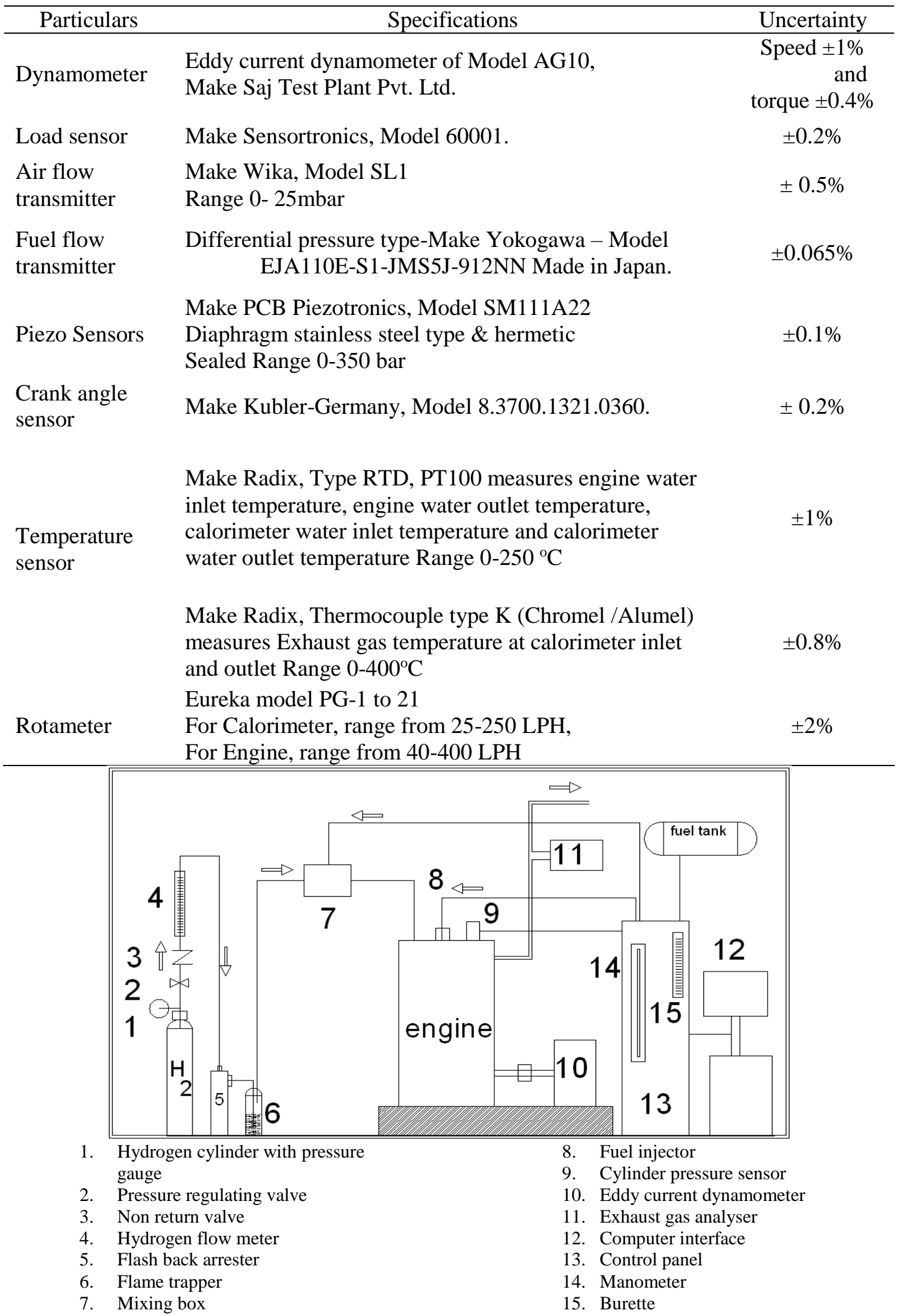

Figure 1. Schematic diagram of the experimental setup. 


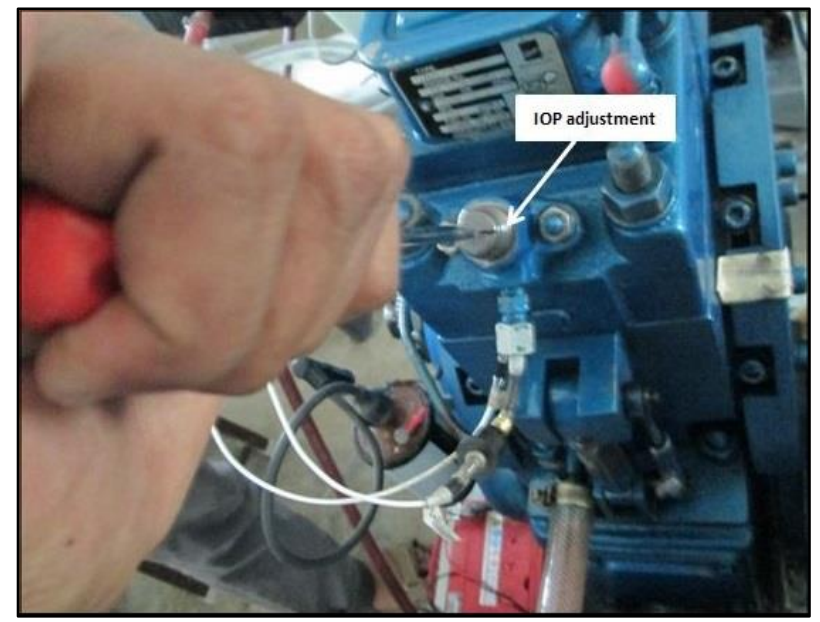

Figure 2. Physical experimental setup for variation in Injection Opening Pressure (IOP).

\section{Mixing of Hydrogen with Air}

Figure 3 shows the modified engine for direct induction of hydrogen through the inlet manifold and the hydrogen pressure was controlled directly by the pressure regulator provided at the hydrogen cylinder opening. The constant speed operation diesel was controlled by the governor mechanism provided in the engine.

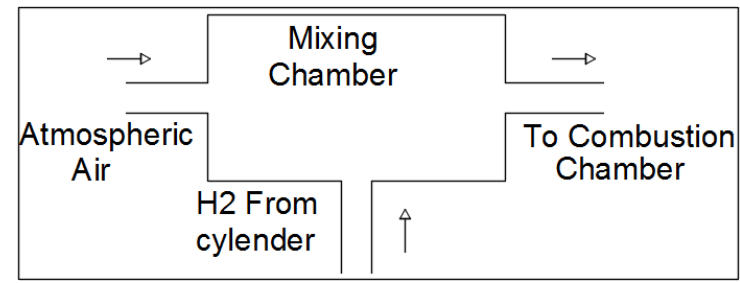

Figure 3. Mixing chamber of hydrogen and air.

\section{Experimentation}

The mass flow rate of the blended fuel was calculated via volumetric basis by using a burette and a stop watch. The exhaust gas temperature was measured by using a thermocouple attached with a digital temperature indicator, while the pressure was recorded by using a piezo pressure sensor fitted in the head of the engine cylinder.

\section{Experimental Procedure}

In the first step of experiment, the engine was operated with pure diesel and its performance and emission characteristics were calculated for three different injection opening pressures. In the second step of experiment, the engine was operated to run with emulsions made with 5WCOBD5PSBD90D, 10WCOBD10PSBD80D and 15WCOBD15PSBD70D for three different injection opening pressure ratios. The 10WCOBD10PSBD70D blend was optimal among those tested in terms of BTE and BSFC. In the third step of experiment, the engine was operated to run with optimal emulsion of the above said biodiesels blended with diesel and compressed hydrogen gas (to further enhance combustion) introduced by induction through the intake manifold at three different flow rates of 4lpm, 6lpm and 81pm as shown in Table 3 . The performance results and emission parameters were compared. 
Table 3. Composition of fuel mixtures and test matrix.

\begin{tabular}{|c|c|c|c|c|c|c|c|}
\hline \multirow{3}{*}{$\begin{array}{l}\text { Spell of } \\
\text { Experiment }\end{array}$} & \multicolumn{3}{|c|}{ Feedstock: \% by volume } & \multirow{2}{*}{\multicolumn{3}{|c|}{$\begin{array}{l}\text { Cycle of Experiment for } \\
\text { different Injection Opening } \\
\text { Pressures (IOPs) }\end{array}$}} & \multirow{3}{*}{$\begin{array}{c}\mathrm{H}_{2} \\
\mathrm{lpm}\end{array}$} \\
\hline & \multirow{2}{*}{$\begin{array}{l}\text { Pure } \\
\text { diesel }\end{array}$} & \multirow{2}{*}{$\begin{array}{l}\text { Waste } \\
\text { cooking } \\
\text { oil } \\
\text { biodiesel }\end{array}$} & \multirow{2}{*}{$\begin{array}{c}\text { Palm } \\
\text { Stearin } \\
\text { Biodiesel }\end{array}$} & & & & \\
\hline & & & & $\mathrm{A}$ & $\mathrm{B}$ & $\mathrm{C}$ & \\
\hline \multirow[t]{2}{*}{1} & 100 & - & - & 200bar & $225 \mathrm{bar}$ & 250bar & - \\
\hline & 90 & 5 & 5 & 200bar & $225 \mathrm{bar}$ & $250 \mathrm{bar}$ & \\
\hline \multirow[t]{3}{*}{2} & 80 & 10 & 10 & 200bar & 225 bar & 250bar & - \\
\hline & 70 & 15 & 15 & $200 \mathrm{bar}$ & $225 \mathrm{bar}$ & $250 \mathrm{bar}$ & \\
\hline & & & & 200bar & 225bar & 250bar & 4 \\
\hline \multirow[t]{2}{*}{3} & 80 & 10 & 10 & 200bar & 225bar & 250bar & 6 \\
\hline & & & & 200bar & $225 \mathrm{bar}$ & $250 \mathrm{bar}$ & 8 \\
\hline
\end{tabular}

Table 4. Fuel properties for pure diesel, biodiesels and diesel blend of dual biodiesel

\begin{tabular}{lcccc}
\hline \multicolumn{1}{c}{ Property } & Diesel & WCOBD & PSBD & B30 \\
& & & & (15WCOBD+15PSBD+70D) \\
\hline Density $\left(\mathrm{kg} / \mathrm{m}^{3}\right)$ & 832 & 878 & 898 & 848.8 \\
Viscosity at $40^{\circ} \mathrm{C}$ & 2.6 & 3.35 & 4.12 & 2.94 \\
$\left(\mathrm{~mm}^{2} / \mathrm{s}\right)$ & 46.049 & 45.080 & 39.507 & 44.922 \\
Calorific value $(\mathrm{MJ} / \mathrm{Kg})$ & & &
\end{tabular}

Table 5. Energy equivalent and energy share.

\begin{tabular}{|c|c|c|c|c|c|c|c|c|c|}
\hline $\begin{array}{l}\text { Strategy of } \\
\text { Experiment }\end{array}$ & $\begin{array}{l}\text { Load } \\
\% \text { age }\end{array}$ & $\begin{array}{c}\text { Energy } \\
\text { Equivalent } \\
\text { of diesel } \\
\text { KW }\end{array}$ & $\begin{array}{c}\text { Energy } \\
\text { Equivalent } \\
\text { of } \\
\text { WCOBD } \\
\text { KW }\end{array}$ & $\begin{array}{c}\text { Energy } \\
\text { Equivalent } \\
\text { of } \\
\text { PSBD } \\
\text { KW }\end{array}$ & $\begin{array}{c}\text { Energy } \\
\text { Equivalent } \\
\text { of } \\
\mathrm{H}_{2} \\
\mathrm{KW}\end{array}$ & $\begin{array}{c}\text { Diesel } \\
\text { Energy } \\
\text { Share } \\
(\%)\end{array}$ & $\begin{array}{c}\text { WCOBD } \\
\text { Energy } \\
\text { Share } \\
(\%)\end{array}$ & $\begin{array}{c}\text { PSBD } \\
\text { Energy } \\
\text { Share } \\
(\%)\end{array}$ & $\begin{array}{c}\mathrm{H}_{2} \\
\text { Energy } \\
\text { Share } \\
(\%)\end{array}$ \\
\hline \multicolumn{10}{|c|}{225 bar } \\
\hline 10WCOBD & 50 & 8.406 & 1.763 & 1.545 & 0.655 & 67.9 & 14.2 & 12.4 & 5.2 \\
\hline +10PSBD & 75 & 9.611 & 2.016 & 1.766 & 0.655 & 68.4 & 14.3 & 12.5 & 4.6 \\
\hline $\begin{array}{l}+80 \mathrm{D}+ \\
\mathrm{H}_{2} 4 \mathrm{lpm}\end{array}$ & 100 & 11.2 & 2.351 & 2.060 & 0.655 & 68.8 & 14.4 & 12.6 & 4.0 \\
\hline 10WCOBD & 50 & 7.081 & 1.485 & 1.301 & 0.983 & 65.2 & 13.6 & 11.9 & 9.0 \\
\hline +10PSBD & 75 & 8.406 & 1.763 & 1.545 & 0.983 & 66.2 & 13.8 & 12.1 & 7.7 \\
\hline $\begin{array}{l}+80 \mathrm{D}+ \\
\mathrm{H}_{2} 61 \mathrm{pm}\end{array}$ & 100 & 9.611 & 2.016 & 1.766 & 0.983 & 66.8 & 14.0 & 12.2 & 6.8 \\
\hline 10WCOBD & 50 & 6.728 & 1.411 & 1.236 & 1.31 & 62.9 & 13.2 & 11.5 & 12.2 \\
\hline +10PSBD & 75 & 8.406 & 1.763 & 1.545 & 1.31 & 64.5 & 13.5 & 11.8 & 10.0 \\
\hline $\begin{array}{l}+80 \mathrm{D}+ \\
\mathrm{H}_{2} 81 \mathrm{pm}\end{array}$ & 100 & 10.350 & 2.171 & 1.902 & 1.31 & 65.7 & 13.7 & 12.0 & 8.3 \\
\hline
\end{tabular}

The calorific value of diesel is higher than its diesel blends due to high oxygen content than fossil diesel [11]. Two main factors that are responsible for higher viscosity and density of biodiesel are large molecular weight and complex chemical structure [1215]. Table 4 reveals that PS biodiesel has less calorific value and lower viscosity and density than WCO biodiesel. For different hydrogen flow rates i.e., 4lpm, 6lpm and 81pm, the mass flow rate of hydrogen at all loads in terms of $\mathrm{kg} / \mathrm{sec}$ was calculated. Then, the energy share of hydrogen $(\mathrm{kW})=$ mass flow rate of hydrogen $(\mathrm{kg} / \mathrm{sec}) \times$ lower calorific value of hydrogen $(\mathrm{kJ} / \mathrm{kg})$. Similarly, the energy share for diesel and biodiesel fuels were calculated by using the formula; energy share $(\mathrm{kW})=$ mass flow rate of main fuel $(\mathrm{kg} / \mathrm{sec})$ $\times$ lower calorific value $(\mathrm{kJ} / \mathrm{kg})$ as shown in Table 5 for 225 bar injection opening pressure. 


\section{RESULTS AND DISCUSSION}

\section{Brake Thermal Efficiency}

Brake thermal efficiency is the indication of the engine ability to transform energy input to useful work. Figure 4 and 5 show the brake thermal efficiency of all test fuels at different injection opening pressures (IOPs). BTE for pure diesel was more than the blends. The slight variations in the thermal efficiency of the biodiesel blends were mainly due to the lower calorific value of WCOBD and PSBD when compared with diesel [16, 17]. Furthermore, the higher viscosity and slow vaporisation of biodiesel present in these blends led to inferior combustion of biodiesel which caused the brake thermal efficiency to be low [18-20] . BTE was lower for B10 and increased with the blending ratio of B20, thereafter, it fell with further increase to B30. The optimum blending ratio was B20. For all IOPs, BTE increased with the increase of load until $75 \%$, thereafter, decreased at full load. Hence, the optimum loading was $75 \%$. In Figure 5, the biodiesel blends in diesel were plotted against different IOPs. From the figure, 225bar was the optimum IOP with maximum BTE for baseline fuel and B20 at $27.44 \%$ and $24.31 \%$, respectively, which were lower than the baseline fuel i.e., diesel by $12.06 \%$. The optimised values i.e., B20 at $225 \mathrm{bar}$ IOP and $75 \%$ loading were further tested with hydrogen induction at different rates of admission.
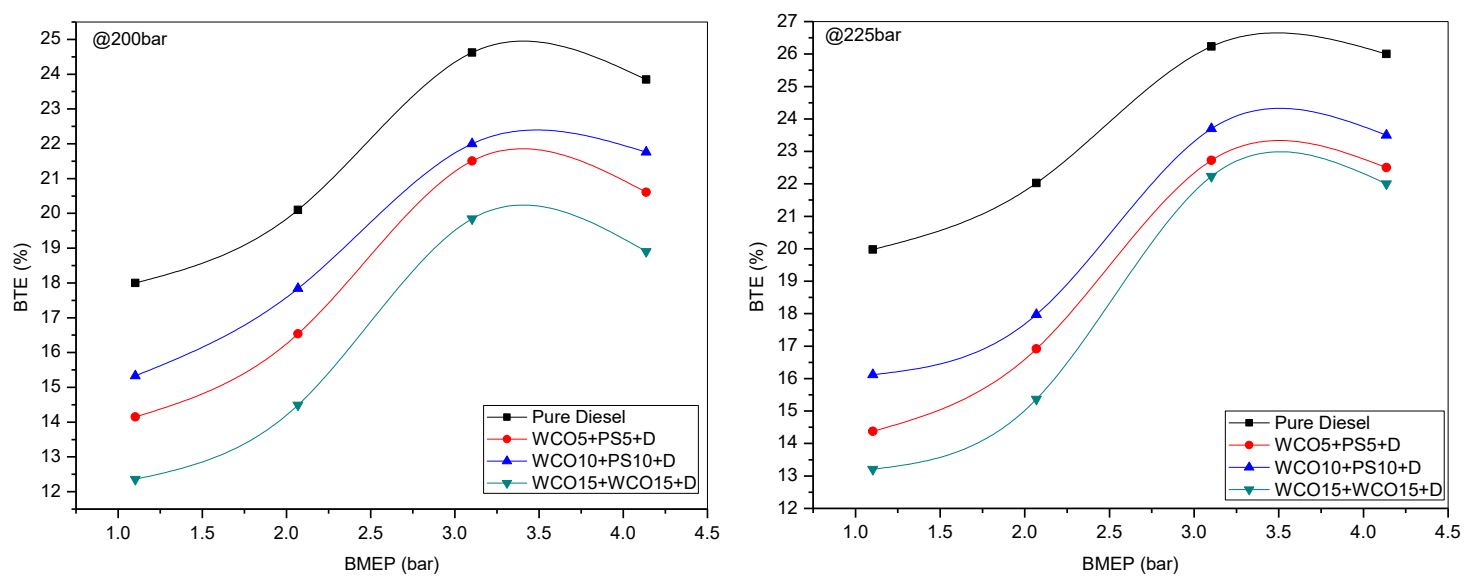

Figure 4. Variation brake thermal efficiency versus brake mean effective pressure at 200 bar and 225 bar injection opening pressures for dual biodiesel blended in diesel.

Figure 6 shows that the peak performance was at $75 \%$ load i.e., $31.3 \%$ with $6 \mathrm{pm}$ $\mathrm{H}_{2}$. The engine conditions became unstable at $100 \%$ loading conditions with reduction in BTE to $29.8 \%$. Therefore, the optimal loading was $75 \%$, this trend was also experienced by previous researchers [21]. The reduced power production faced by the biodiesel combustion was resolved by hydrogen that assisted dual biodiesel blends of diesel fuel combustion, examined as a promising solution to enhance biodiesel combustion processes [22]. With the induction of hydrogen in dual biodiesel blended with diesel, the brake thermal efficiencies were $29.31 \%, 31.3 \%, 30.5 \%$ for 4,6 , and $81 \mathrm{pm}$, respectively, which were $20.56 \%, 28.75 \%$ and $25.46 \%$ more compared to biodiesel. Large amount of heat energy was released when the injection pressures were increased in the CI engine, thereby, the ignition delay was reduced and the fuel became completely burnt [23]. Figure 7 shows the increase of brake thermal efficiency from IOP of 200bar to 225 bar. With further increase of injection IOP i.e., to 250 bar, the ignition delay period decreased, which in 
turn decreased the homogeneous mixing that led to incomplete combustion and less brake thermal efficiency.
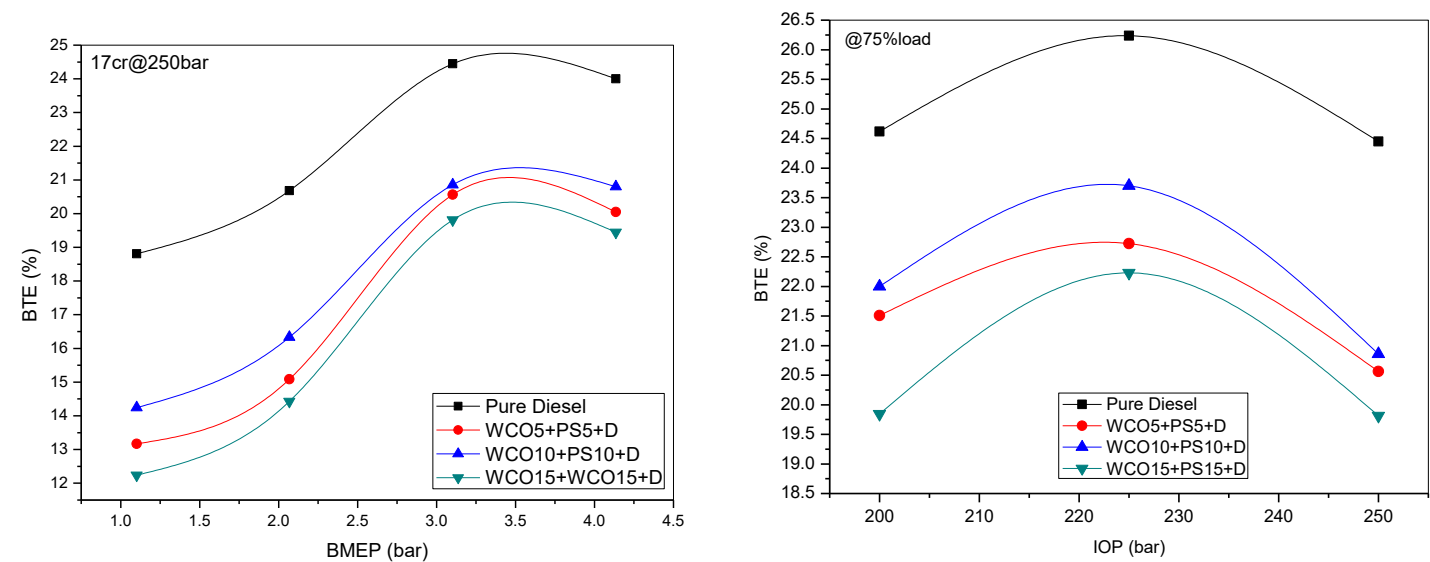

Figure 5. Variation brake thermal efficiency versus brake mean effective pressure at 250 bar and all injection opening pressures for dual biodiesel blended in diesel.
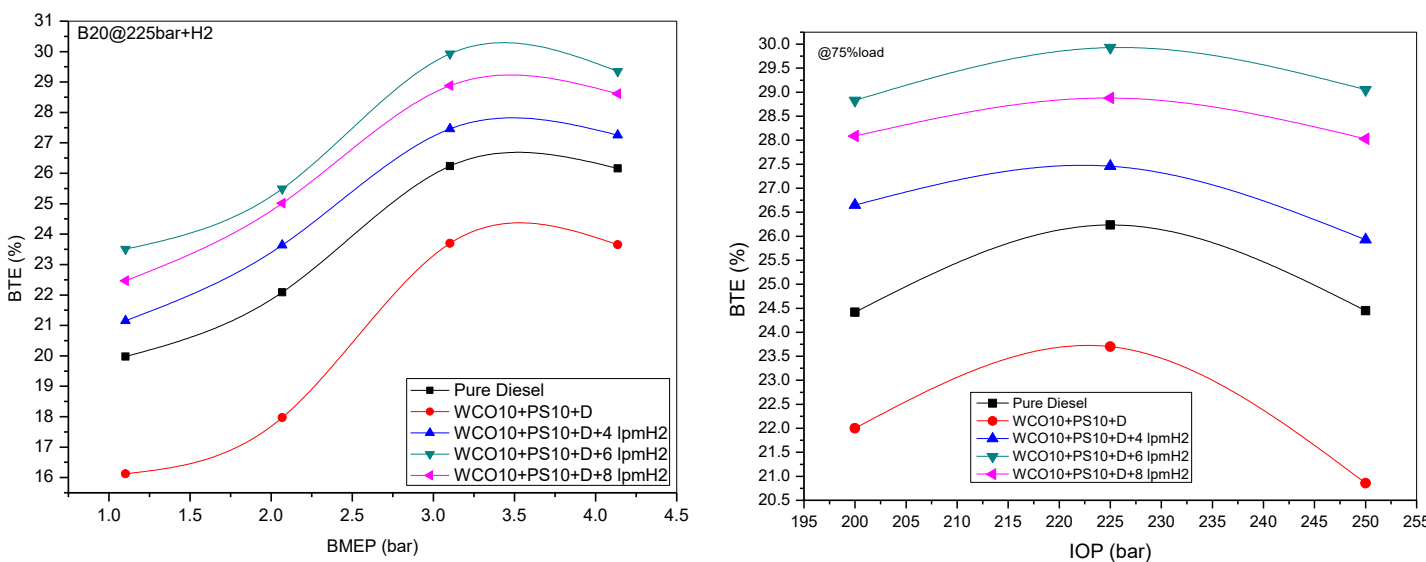

Figure 6 Variation brake thermal efficiency versus brake mean effective pressure at 225 bar and injection opening pressure at $75 \%$ load for dual biodiesel blended in diesel along with hydrogen induction.

\section{Brake Specific Energy Consumption}

Brake specific fuel consumption is the ratio between mass flow rate of the tested fuel and effective power [11]. The brake specific fuel consumption of CI engine depends on the relationship among volumetric fuel injection system, density of fuel, lower heating value and viscosity [24]. Brake specific energy consumption is a more authentic parameter for comparing fuels with different calorific values and densities. This energy consumption can be obtained as the product of brake specific fuel consumption and calorific value of the fuel. The energy equivalents and energy shares are shown in Table 5 for B20 along with 4, 6 and $8 \mathrm{lpm}$ rate of hydrogen induction.

The variation of brake specific energy consumption (BSEC) with brake mean effective pressure (BMEP) for different fuels is presented in Figure 7. The reason for the higher BSEC of biodiesels in Figure 7 can be attributed to the combined effects of the three variables i.e., relative fuel density, viscosity and heating value of the blends [25]. Biodiesel fuel was administered in the engine on a volumetric basis per stroke, thus, larger quantities of biodiesel were nourished into the engine. Hence, to produce the same power, 
excess biodiesel fuel was needed due to its less calorific value compared to diesel fuel $[26,27]$. BSEC reduced with the increase in injection pressure for all fuels tested. This was due to the better atomisation at higher injection pressure which exhibited more surface area of fuel droplets to the high temperature air salient to complete fuel combustion [28]. Further increase in IOP, i.e., 250 bar, decreased the ignition delay, which in turn decreased homogeneous mixing possibility and led to incomplete combustion, hence, more BSEC. A similar trend was observed by previous researchers [11]. The hydrogen-assisted combustion dual biodiesel blends showed a decrease in BSEC with increasing flow of hydrogen, which can be attributed to the uniform mixing of hydrogen with air and diffusivity and led to the near complete combustion of the fuel. For this reason, the fuel consumption was decreased.
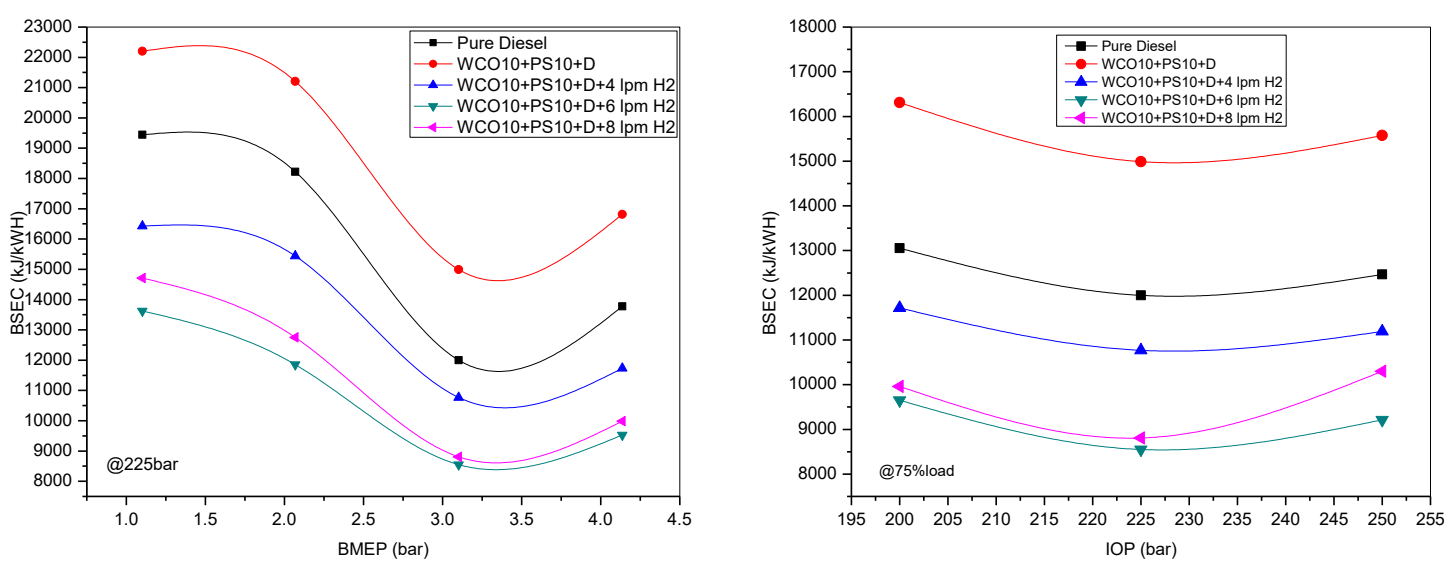

Figure 7 Variation brake specific energy consumption versus brake mean effective pressure at 225bar and for injection prresure at $75 \%$ load for dual biodiesel blended in diesel along with hydrogen induction at three different rates.

\section{Emission Analysis}

The emission constituents considered were carbon monoxide $(\mathrm{CO})$, oxides of nitrogen $\left(\mathrm{NO}_{\mathrm{x}}\right)$ and unburned hydrocarbon (HC). The effect of IOP on the emission constituents for Diesel+WCOBD+PSBD blends and diesel for different test pressures are shown in Figure 8 and 9. Features like higher cetane number than diesel and less sulphur and more oxygen, are environmentally friendly and can reduce $\mathrm{HC}$ and $\mathrm{CO}$ in the exhaust gas. For these reasons, different studies have been conducted on biodiesel blended with diesel and the results show that emission concentration varies and depends on biodiesel source and engine condition [14, 20, 29]. Hydrogen possesses many superior combustion and emission characteristics than other liquid or gas fuels. For instance, due to the omission of the carbon atom, hydrogen combustion does not produce any harmful emissions such as $\mathrm{HC}, \mathrm{CO}$, sulphur oxides, or organic acids [30].

\section{Carbon Monoxide Emission}

Figure 8 shows the effect of IOP on $\mathrm{CO}$ for biodiesel and biodiesel blends of diesel. The $\mathrm{CO}$ emission reduced with increased IOP. This may be due to the fuel being atomised into very fine droplets and more surface areas were accessible for combustion, which resulted in the formation of a good quality fuel mixture that caused a complete combustion [28]. Whereas for pressure of $250 \mathrm{bar}$, the performance drop led to an incomplete combustion which resulted in the increase of $\mathrm{CO}$ emission at all loads. Consistent and 
tangible reduction in $\mathrm{CO}$ emission were found at $75 \%$ load with 225 bar pressure for dual biodiesel blended with diesel $0.08 \%$ and the reduction percentages in the $\mathrm{CO}$ emission were $7.5 \%, 26.257 \%$ and 12.5\% with $4 \mathrm{lpm}, 6 \mathrm{lpm}$ and $8 \mathrm{lpm}$ of $\mathrm{H}_{2}$ induction to emulsified fuel. The primary reason for the reduced $\mathrm{CO}$ emission was due to the decrease in the amount of total carbon in the inducted fuel.
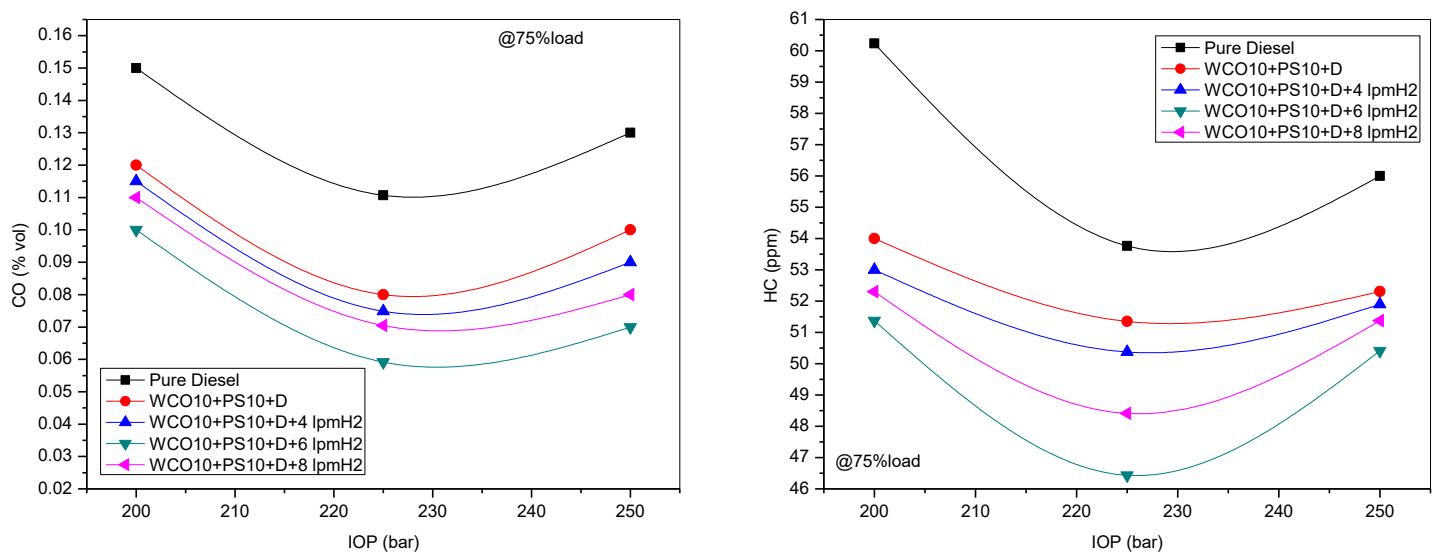

Figure 8. Variation of carbon monoxide and unburned hydrocarbon versus injection opening pressure at $75 \%$ load for dual biodiesel blended in diesel along with hydrogen induction at three different rates.

\section{Unburned Hydrocarbon}

The unburned hydrocarbon of tested engine with different injection pressures for the pilot fuel, base line fuel and fuel with hydrogen induction is shown in Figure 8. HC emission reduced with increased IOP of engine for base line fuel, biodiesel blended diesel mixture and biodiesel blended diesel mixture with hydrogen. $\mathrm{HC}$ emission increased for all test fuels with load, and there was a reduction in $\mathrm{HC}$ emission for biodiesel compared to diesel due to the presence of oxygen in its molecular structure that led to an efficient combustion $[29,31]$. The decreasing trend of UHC was observed with increasing \%age of $\mathrm{H}_{2}$ substitution when compared with pure diesel because of its high flammability limit and calorific value [32]. At 225 bar, proper atomisation and mixing with maximum \%age of burnt carbon content were achieved and UHC formation was greatly minimised.

\section{Oxides of Nitrogen $\left(\mathrm{NO}_{\mathrm{x}}\right)$ Emission}

Comparison of $\mathrm{NO}_{\mathrm{x}}$ emission for different injection pressures of the test fuels is illustrated in Figure 9. The $\mathrm{NO}_{\mathrm{x}}$ emission level increased with increasing injection pressure because of a faster combustion and greater cylinder gas temperature due to peak pressure which occurred at the earlier crank angle $[19,33]$. At pressure of 225bar, the $\mathrm{NO}_{\mathrm{x}}$ emissions were $802.1 \mathrm{ppm}, 890 \mathrm{ppm}, 952.16 \mathrm{ppm}, 1020.12 \mathrm{ppm}$ and $1103.52 \mathrm{ppm}$ for base line fuel, dual biodiesel blends of diesel, emulsified fuel with 4lpm, 6lpm, and 81pm of $\mathrm{H}_{2}$ induction, respectively. But this could be potentially established by the use of EGR technique and emulsified biodiesel as presented by Korakianitis et al. [34]. Nevertheless, a contrary trend was also observed by other researchers who claimed that the $\mathrm{NO}_{\mathrm{x}}$ emissions were smaller for dual fuel combustion, particularly at medium and high engine loads, and they attributed it to the combined effects of hydrogen incantation and late pilot fuel injection, that contributed to low temperature combustion [35, 36]. Experimental and simulated analysis of inline cylinder pressure for $\mathrm{B} 20+61 \mathrm{pm} \mathrm{H}_{2}$. Pressure and temperature contours for bio-diesel 10WCOBD+10PSBD+80D+6lpm $\mathrm{H}_{2}$. From Figure 10, it can be 
seen that the experimented and simulated peak pressures for 10WCOBD+10PSBD+80D+6lpm $\mathrm{H}_{2}$ were $68.95 \mathrm{bar}$ and $70.87 \mathrm{bar}$, respectively, with a variation of approximately $2.78 \%$.

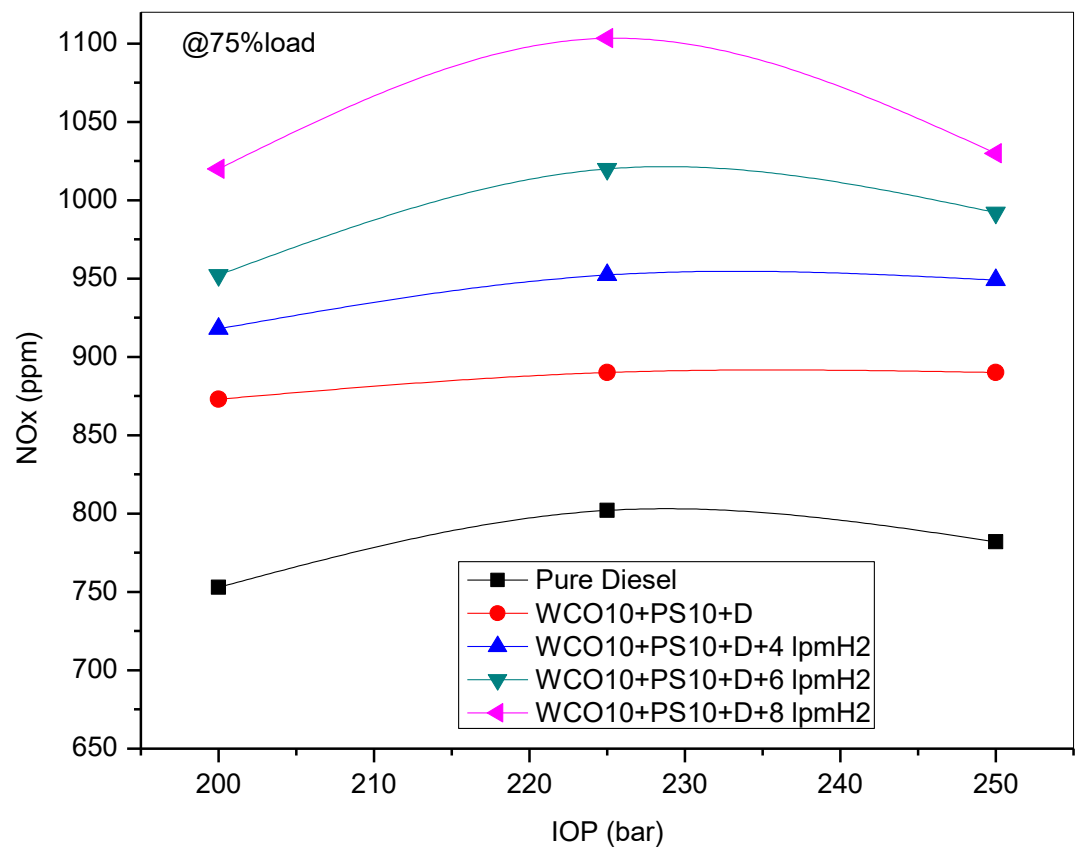

Figure 9. Variation of oxides of nitrogen versus injection opening pressure at $75 \%$ load for dual biodiesel blended in diesel along with hydrogen induction at three different rates.

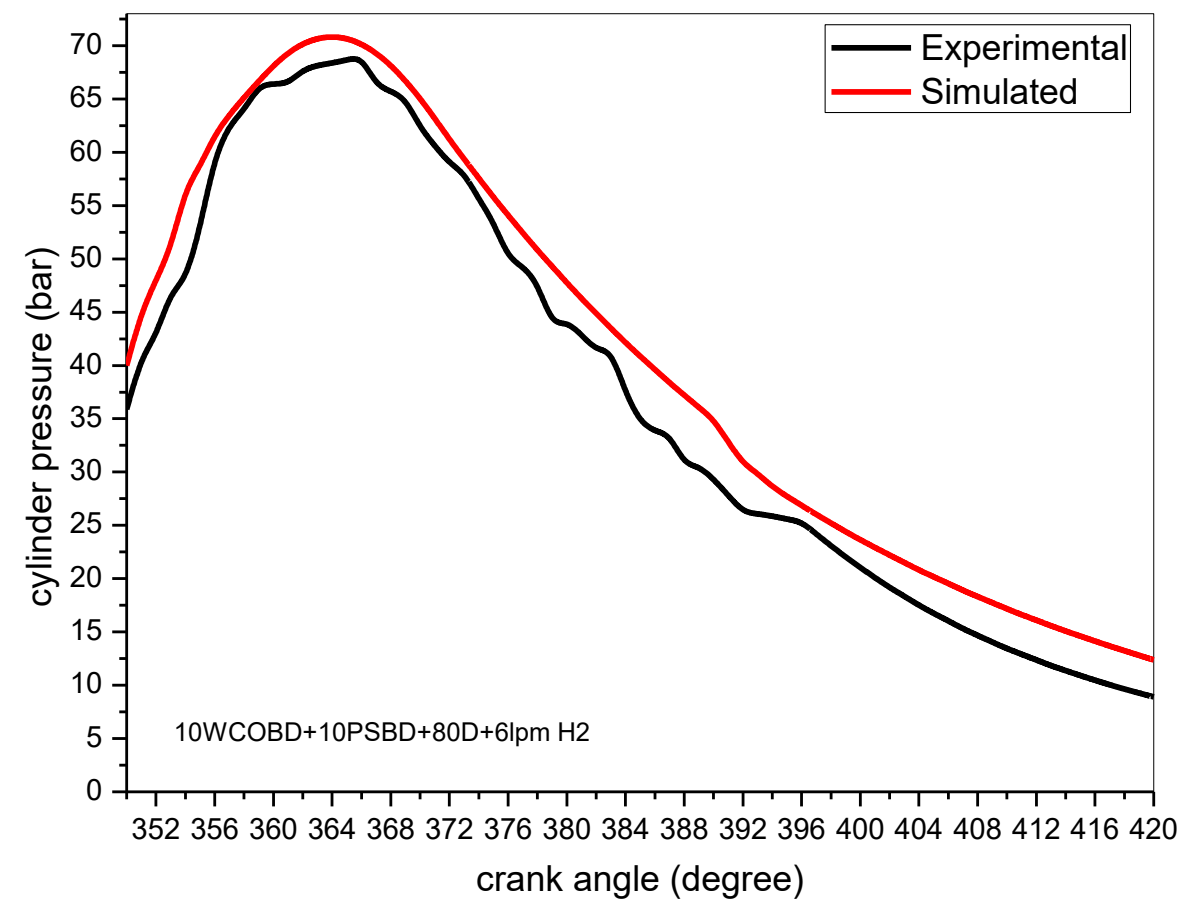

Figure 10. Comparison of simulated and experimental values of peak in-cylinder pressures against crank angles for 10WCOBD+10PSBD+80D+6lpm $\mathrm{H}_{2}$. 


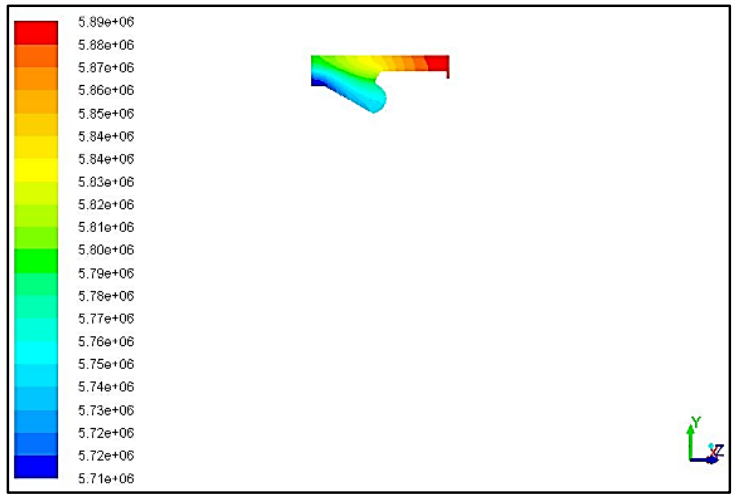

(a)

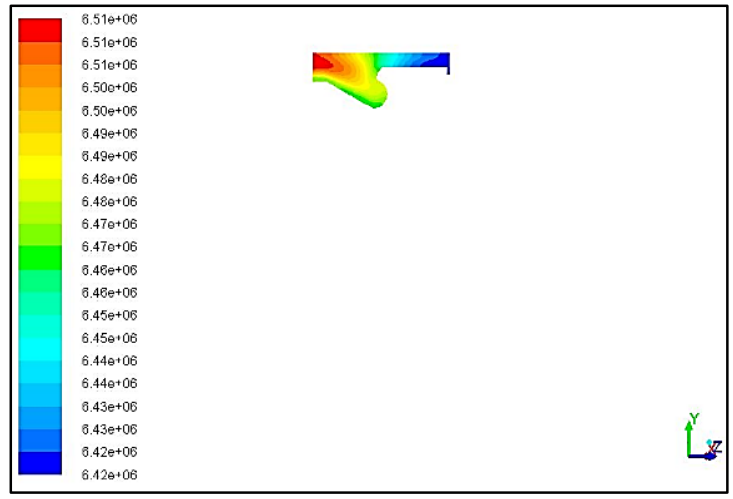

(b)

Figure 11. Pressure contour at crank angle (a) 352 degree and (b) 364 degree for 10WCOBD+10PSBD+80D+6lpm $\mathrm{H}_{2}$.

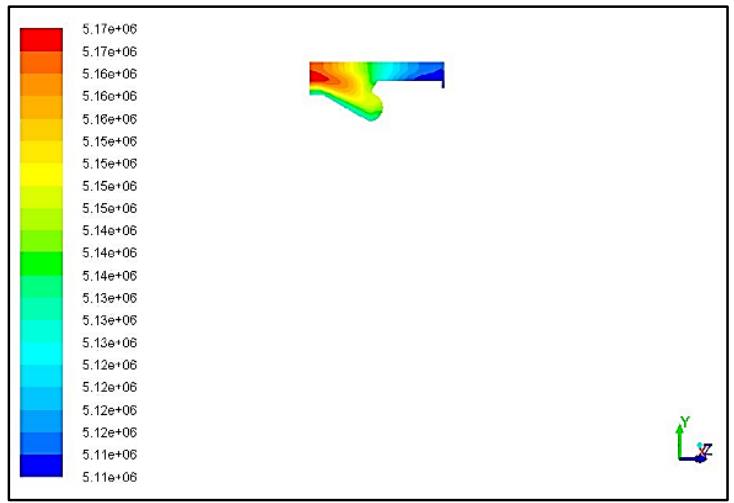

(a)

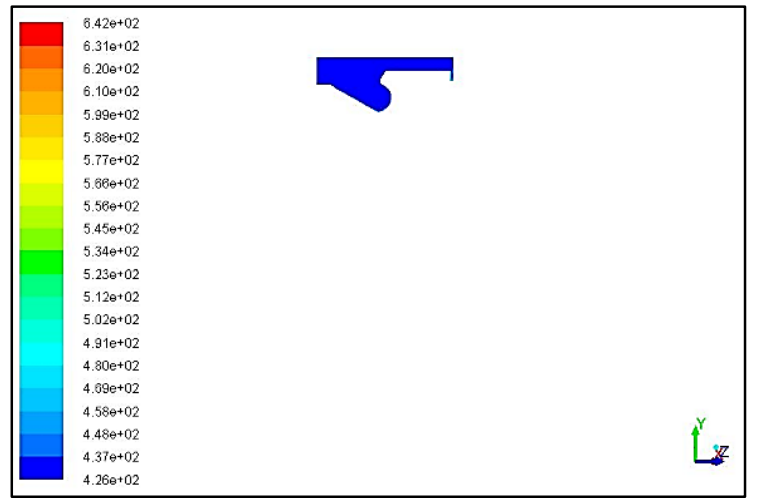

(b)

Figure 12. Pressure and temperature contours at crank angle (a) 372 degree and (b) 364 degree, respectively for $10 \mathrm{WCOBD}+10 \mathrm{PSBD}+80 \mathrm{D}+61 \mathrm{pm} \mathrm{H}_{2}$.

\section{CONCLUSIONS}

Based on the experimental investigation to study the performance, emission and combustion characteristics of a single cylinder diesel engine using treble biodiesel blended with conventional diesel, which included hydrogen as the third biofuel to assist the combustion, the following conclusions were drawn:

- Emulsifying WCOBD and PSBD in conventional diesel to 10WCOBD10PSBD80D proportion; thermal efficiency decreased by $12.06 \%$.

- BSEC was increased by $24.94 \%$ i.e., $11997.22 \mathrm{kj} / \mathrm{kwh}$ for diesel and $14990.49 \mathrm{kj} / \mathrm{kwh}$ for emulsified fuel

- BSEC for optimal blend i.e., B20+6lpm $\mathrm{H}_{2}$ was $8550.89 \mathrm{~kJ} / \mathrm{kwh}$, which was less than diesel.

- $\mathrm{CO}$ emission decreased by $27.27 \%$ i.e., for diesel CO was $0.11 \%$ and emulsified fuel was $0.08 \%$. HC emission for diesel was $53.768 \mathrm{ppm}$ and biodiesel blend was $51.354 \%$ (decreased by $4.48 \%$ ). No showed an increasing trend, $802.14 \mathrm{ppm}$ for diesel and 890ppm for biodiesel blend, which was $10.95 \%$ more.

- As emulsified fuel was assisted by hydrogen induced combustion, the performance was increased with respect to the base line test fuel i.e., diesel, BTE being $26.2354 \%$ and $29.9314 \%$, respectively, for an increase of $14.08 \%$. BSEC decreased by $28.72 \%$. 
- CO emission decreased i.e., $0.05915 \%$ and $011071 \%$ for hydrogen assisted and pure diesel, respectively. $\mathrm{HC}$ emission decreased by $13.63 \%$. $\mathrm{No}_{\mathrm{x}}$ increased by $37.53 \%$ i.e., 1103.52ppm and $802.144 \mathrm{ppm}$, respectively.

- Best injection opening pressure was 225bar, where all parameters were optimised.

- Data acquisition was done after normalising the engine and $75 \%$ loading condition for all test fuel was optimum.

- Hydrogen induction was done at three different rates and 4lpm was the ideal rate, where the operating condition was optimum.

- Induction of hydrogen inline of biodiesel had outlaid the performance of diesel as a stand-alone fuel. Difficulty in storage and transportation only.

Maximum utilisation of WCO is recommended to convert it to biodiesel, with a neat disposal to ovoid spill that can damage the environment. Hydrogen induction enhances engine performance.

\section{ACKNOWLEDGEMENTS}

Author acknowledge contribution of Methodist College of Engineering \& Technology for sparing time and money behind the research finding and Dr. S. Azam Pasha Quadri at Lords Institute of Engineering \& Technology for providing logistical support.

\section{REFERANCES}

[1] Adam IK, A. Aziz AR, Yusup S. Determination of diesel engine performance fueled biodiesel (rubber seed/palm oil mixture) diesel blend. International Journal of Automotive and Mechanical Engineering. 2015;11:2675-85.

[2] Pai PS, Rao BS. Artificial neural network based prediction of performance and emission characteristics of a variable compression ratio CI engine using WCO as a biodiesel at different injection timings. Applied Energy. 2011;88:2344-54.

[3] Belyamin B, Noor AM, Hussein MH, Said M. Characterization of Diesel Engine Generator Operating at Different Compression Ratio Fuelled with Palm Oil Biodiesel. Applied Mechanics and Materials: Trans Tech Publ; 2013. p. 241-5.

[4] Hoque N, Mourshed M, Das BK. Performance and emission comparison of Karanja (pongamia pinnata), Pithraj (aphanamixis polystachya), Neem (azadira chtaindica) and Mahua (madhuca longofolia) seed oil as a potential feedstock for biodiesel production in Bangladesh. International Journal of Automotive and Mechanical Engineering. 2015;12:2967-82.

[5] Zheng S, Kates M, Dubé M, McLean D. Acid-catalyzed production of biodiesel from waste frying oil. Biomass and bioenergy. 2006;30:267-72.

[6] Tomasevic A, Siler-Marinkovic S. Methanolysis of used frying oil. Fuel Processing Technology. 2003;81:1-6.

[7] Tao Y, Chen Y, Wu Y, He Y, Zhou Z. High hydrogen yield from a two-step process of dark-and photo-fermentation of sucrose. International Journal of Hydrogen Energy. 2007;32:200-6.

[8] Simbollotti G. IEA Energy Technology Essentials-Hydrogen Production and Distribution. International Energy. 2017;544.

[9] Laia O, Ghazalia H, Cho F, Chong C. Physical and textural properties of an experimental table margarine prepared from lipase-catalysed transesterified palm stearin: palm kernel olein mixture during storage. Food Chemistry. 2000;71:173-9.

[10] Xing X, Zhang C. Research progress in dark microbial fermentation for bio-hydrogen production. Chinese Journal of Bioprocess Engineering. 2005;3:1-8. 
[11] Mofijur M, Masjuki H, Kalam M, Atabani A. Evaluation of biodiesel blending, engine performance and emissions characteristics of Jatropha curcas methyl ester: Malaysian perspective. Energy. 2013;55:879-87.

[12] Agarwal AK. Biofuels (alcohols and biodiesel) applications as fuels for internal combustion engines. Progress in Energy and Combustion Science. 2007;33:233-71.

[13] Nalgundwar A, Paul B, Sharma SK. Comparison of performance and emissions characteristics of DI CI engine fueled with dual biodiesel blends of palm and jatropha. Fuel. 2016;173:172-9.

[14] Khalid A, Tajuddin ASA, Jaat N, Manshoor B, Zaman I, Hadi SAA, et al. Performance and emissions of diesel engine fuelled with preheated biodiesel fuel derived from crude palm, jatropha, and waste cooking oils. International Journal of Automotive and Mechanical Engineering. 2017;14:4273-84.

[15] Shukri MR, Rahman MM, Ramasamy D, Kadirgama K. Artificial neural network optimization modeling on engine performance of diesel engine using biodiesel fuel. International Journal of Automotive and Mechanical Engineering. 2015;11:2332-47.

[16] Nayak SK, Mishra PC. Emission from a dual fuel operated diesel engine fuelled with Calophyllum Inophyllum biodiesel and producer gas. International Journal of Automotive and Mechanical Engineering. 2017;14:3954-69.

[17] Dubey P, Gupta R. Study of the performance and emission characteristics for a dual fuel powered single cylinder diesel engine. International Journal of Automotive and Mechanical Engineering. 2016;13:3373-88.

[18] Anand R, Kannan G, Karthikeyan P. A Study of the Performance Emission and Combustion Characteristics of a DI Diesel Engine Using Waste Cooking Oil Methyl Ester-Ethanol Blends. ASME 2012 International Mechanical Engineering Congress and Exposition: American Society of Mechanical Engineers; 2012. p. 935-42.

[19] Reddy JN, Ramesh A. Parametric studies for improving the performance of a Jatropha oil-fuelled compression ignition engine. Renewable Energy. 2006;31:19942016.

[20] Jaat N, Khalid A, Andsaler AR, Sapit A, Razali A, Basharie M. Effects of ambient temperature and injection pressure on biodiesel ignition delay. Journal of Mechanical Engineering and Sciences. 2017;11:2723-33.

[21] Jegadheesan C, Somasundaram P, Meenakshipriya B, Vignesh U. Effect of DEE Injection in Pongamia Pinnata Biodiesel Fulled CI Engine Using Hydrogen as Secondary Fuel. Advanced Materials Research: Trans Tech Publ; 2013. p. 188-94.

[22] An H, Yang W, Maghbouli A, Li J, Chou S, Chua KJ, et al. Numerical investigation on the combustion and emission characteristics of a hydrogen assisted biodiesel combustion in a diesel engine. Fuel. 2014;120:186-94.

[23] Mahalingam S, Suresh M, Pranesh R. Experimental study of performance and emission characteristics of a bio dual fuel blends in diesel engine for variation of injection pressures. Proceedings of the World Congress on Engineering: Citeseer; 2013.

[24] Qi D, Chen H, Geng L, Bian YZ. Experimental studies on the combustion characteristics and performance of a direct injection engine fueled with biodiesel/diesel blends. Energy Conversion and Management. 2010;51:2985-92.

[25] Chauhan BS, Kumar N, Cho HM. A study on the performance and emission of a diesel engine fueled with Jatropha biodiesel oil and its blends. Energy. 2012;37:616-22.

[26] Lin B-F, Huang J-H, Huang D-Y. Experimental study of the effects of vegetable oil methyl ester on DI diesel engine performance characteristics and pollutant emissions. Fuel. 2009;88:1779-85.

[27] Tsolakis A, Megaritis A, Wyszynski M, Theinnoi K. Engine performance and emissions of a diesel engine operating on diesel-RME (rapeseed methyl ester) blends with EGR (exhaust gas recirculation). Energy. 2007;32:2072-80. 
[28] Channapattana S, Pawar AA, Kamble PG. Effect of injection pressure on the performance and emission characteristics of VCR engine using honne biodiesel as a fuel. Materials Today: Proceedings. 2015;2:1316-25.

[29] Sasongko MN, Wijayanti W. Effect of ethanol addition on the performance and exhaust emissions of a spark ignition engine. Journal of Mechanical Engineering and Sciences. 2017;11:2734-42.

[30] SinghYadav V, Soni S, Sharma D. Performance and emission studies of direct injection CI engine in duel fuel mode (hydrogen-diesel) with EGR. International Journal of Hydrogen Energy. 2012;37:3807-17.

[31] Bhaskar K, Sendilvelan S, Muthu V, Aravindraj S. Performance and emission characteristics of compression ignition engine using methyl ester blends of jatropha and fish oil. J Mech Eng Sci. 2016;10:1994-2007.

[32] Quadri SAP, Masood M, Kumar PR. Effect of pilot fuel injection operating pressure in hydrogen blended compression ignition engine: An experimental analysis. Fuel. 2015;157:279-84.

[33] Bari S, Yu C, Lim T. Effect of fuel injection timing with waste cooking oil as a fuel in a direct injection diesel engine. Proceedings of the Institution of Mechanical Engineers, Part D: Journal of Automobile Engineering. 2004;218:93-104.

[34] Korakianitis T, Namasivayam A, Crookes R. Diesel and rapeseed methyl ester (RME) pilot fuels for hydrogen and natural gas dual-fuel combustion in compressionignition engines. Fuel. 2011;90:2384-95.

[35] Miyamoto T, Hasegawa H, Mikami M, Kojima N, Kabashima H, Urata Y. Effect of hydrogen addition to intake gas on combustion and exhaust emission characteristics of a diesel engine. International Journal of Hydrogen Energy. 2011;36:13138-49.

[36] Yoon SH, Lee CS. Experimental investigation on the combustion and exhaust emission characteristics of biogas-biodiesel dual-fuel combustion in a CI engine. Fuel Processing Technology. 2011;92:992-1000.

\section{NOMENCLATURES}

$\begin{array}{ll}\text { WCOBD } & \text { Waste cooking oil biodiesel } \\ \text { PSBD } & \text { Palm stearin biodiesel } \\ \text { B10(5WCOBD5PSBD90D) } & \text { 5\%WCOBD+5\%PSBD+90\%Diesel } \\ \text { B20(10WCOBD10PSBD80D) } & 10 \% \text { WCOBD+10\%PSBD+80\%Diesel } \\ \text { B30(15WCOBD15PSBD70D) } & 15 \% \text { WCOBD+15\%PSBD+70\%Diesel } \\ \text { lpm } & \text { Liters per minute } \\ \mathrm{CO} & \text { Carbon monoxide } \\ \mathrm{HC} & \text { Hydro carbon } \\ \mathrm{CO}_{2} & \text { Carbon dioxide } \\ \text { NOx } & \text { Oxides of nitrogen } \\ \text { BTE } & \text { Brake thermal efficiency } \\ \text { BSFC } & \text { Brake specific fuel consumption } \\ \text { BSEC } & \text { Brake specific energy consumption } \\ \text { IOP } & \text { Injection opening pressure } \\ \text { CR } & \text { Compression ratio } \\ \text { WCO } & \text { Waste cooking oil } \\ \text { PS } & \text { Palm stearin }\end{array}$

